\title{
Hubungan Pengetahuan Sikap Ibu Dalam Praktik Pemberian Asi Ekslusif Di Wilayah Kerja Puskesmas Pekapuran Raya Kecamatan Banjarmasin Timur Kota Banjarmasin Tahun 2018
}

\author{
Khairul Anam, SH., M.Kes, Elsi Setiandari L.O, SKM., M.Kes \\ Eka Handayani, S.ST,. M.Kes \\ Fakultas Kesehatan Masyarakat Universitas Islam Kalimantan (UNISKA) Banjarmasin \\ Email : khairulanam6767@gmail.com
}

DOI: https://doi.org/10.33859/dksm.v10i2.526

\begin{abstract}
Abstrak
Latar Belakang: Tingkat pemberian Air Susu Ibu (ASI) ekslusif di Indonesia masih sangat rendah yaitu $15,3 \%$. Beberapa faktor diduga menyebabkan bayi tidak mendapatkan ASI dengan baik. Faktor tersebut adalah faktor karakteristik ibu, faktor bayi, lingkungan, dukungan keluarga, pendidikan kesehatan, sosial ekonomi dan budaya. Selain itu, berdasarkan beberapa laporan studi tentang permasalahan pemberian ASI Eksklusif menemukan faktor-faktor tidak diberikannya ASI eksklusif pada bayi adalah karena pengetahuan ibu yang kurang, sikap ibu terhadap pemberian asi ekslusif, ibu sibuk bekerja, pendidikan ibu yang rendah, gencarnya periklanan tentang penggunaan susu formula, kurangnya sekresi ASI, persepsi tentang bayi tanpa diberi makanan tambahan akan menjadi lapar dan pengetahuan ibu tentang ASI kurang.
\end{abstract}

Tujuan: Mengetahui Hubungan Pengetahuan Sikap Ibu Dalam Praktik Pemberian Asi Ekslusif Di Wilayah Kerja Puskesmas Pekapuran Raya Kecamatan Banjarmasin Timur Kota Banjarmasin Tahun 2018

Metode: Penelitian ini menggunakan teknik pengambilan sampel non probability sampling yaitu accidental sampling.

Hasil: Hasil pengumpulan data dianalisis dengan menggunakan statistik univariat dan bivariat menggunakan uji statistik yang dilakukan berupa Uji Statistik Chi-Square. membandingkan frekuensi yang terjadi (observasi) dengan frekuensi harapan (ekspektasi), uji tersebut dilakukan dengan tingkat kemaknaan $\alpha=0,05$. Ada hubungan yang signifikan antara variabel bebas yaitu pengetahuan ibu dengan variabel terikat yaitu Pemberian ASI Ekslusif ( $p$ value $=0,000$ ) di wilayah kerja Puskesmas Pekapuran Banjarmasin.

Simpulan: Ada hubungan yang signifikan antara variabel bebas yaitu sikap ibu dengan variabel terikat yaitu Pemberian ASI Ekslusif ( $\mathrm{p}$ value $=0,000$ ) di wilayah kerja Puskesmas Pekapuran Banjarmasin.

Kata kunci : ASI Eksklusif, Pengetahuan, dan Sikap 


\begin{abstract}
Background: The level of exclusive breastfeeding in Indonesia is still very low at 15.3\%. Several factors are thought to cause babies not to get breast milk properly. These factors are maternal characteristics, infant factors, environment, family support, health education, socio-economic and cultural factors. In addition, based on several study reports on the issue of exclusive breastfeeding finding factors that are not given exclusive breastfeeding to infants is due to lack of mother's knowledge, mother's attitude towards exclusive breastfeeding, working mothers, low maternal education, incessant advertising about milk use formula, lack of ASI secretion, perception of infants without being given additional food will become hungry and maternal knowledge about ASI is lacking.

Aim: Knowing the Relationship between Knowledge of Mother's Attitude in the Practice of Giving Exclusive Asi in the Working Area of Pekapuran Raya Health Center, East Banjarmasin District, Banjarmasin City in 2018

Method: This study uses a non probability sampling technique that is accidental sampling.

Results: The results of data collection were analyzed using univariate and bivariate statistics using statistical tests conducted in the form of Chi-Square Statistic Test. comparing the frequency that occurs (observation) with the frequency of expectations (expectations), the test is carried out with a significance level of $\alpha=0.05$. There is a significant relationship between the independent variables, namely the knowledge of mothers with the dependent variable, namely the provision of exclusive breastfeeding ( $p$ value $=0,000$ ) in the working area of the Pekapuran Public Health Center in Banjarmasin.

Conclusion: There is a significant relationship between the independent variables, namely the attitude of the mother with the dependent variable, namely the provision of exclusive breastfeeding ( $p$ value $=0,000$ ) in the work area of Pekapuran Public Health Center, Banjarmasin.
\end{abstract}

Keywords: Exclusive breastfeeding, knowledge and attitude

\section{Pendahuluan}

Rendahnya pemberian ASI merupakan ancaman bagi tumbuh kembang anak yang akan berpengaruh pada pertumbuhan dan perkembangan kualitas SDM secara umum. $80 \%$ perkembangan otak anak dimulai sejak dalam kandungan sampai usia 3 tahun yang dikenal dengan periode emas, sehingga sangat penting untuk mendapatkan ASI yang mengandung protein, karbohidrat, lemak dan mineral yang dibutuhkan bayi, oleh karena itu diperlukan pemberian ASI ekslusif selama enam bulan dan dapat dilanjutkan hingga dua tahun (Budiharja, 2011).

Pemberian ASI Eksklusif pada bayi merupakan cara terbaik bagi peningkatan kualitas Sumber Daya Manusia (SDM) sejak 
dini. Di Indonesia, Departemen Kesehatan

Republik Indonesia melalui program

perbaikan gizi masyarakat telah menargetkan

cakupan ASI eksklusif 6 bulan sebesar $80 \%$.

Namun demikian, angka ini sangat sulit untuk

dicapai, bahkan tren prevalensi ASI eksklusif

dari tahun ke tahun terus menurun. Hal tersebut sangat memprihatinkan mengingat ASI eksklusif sangat penting bagi tumbuh kembang bayi.

Pemberian ASI eksklusif atau menyusui eksklusif adalah hanya menyusui bayi dan tidak memberi bayi makanan atau minuman lain, termasuk air putih, kecuali obat-obatan dan vitamin atau mineral tetes; ASI perah juga diperbolehkan, yang dilakukan sampai bayi berumur 6 bulan (Depkes, 2005).

Beberapa hasil riset menunjukkan bahwa berbagai dampak buruk dapat terjadi pada bayi bila tidak mendapat Air Susu Ibu (ASI). Berdasarkan penelitian (Lucas, 1992 dalam Masora, 2003) diketahui bahwa IQ kelompok bayi prematur yang diberi ASI adalah 8.5 poin lebih tinggi dibandingkan kelompok bayi yang diberikan susu formula.
Selain itu kurangnya atau tidak diberikannya ASI pada bayi dapat memberikan dampak lainya, baik dampak fisiologis, psikologis sampai kondisi terburuk pada bayi yaitu kematian pada bayi (Bobak, 2000).

Beberapa faktor diduga menyebabkan bayi tidak mendapatkan ASI dengan baik. Faktor tersebut adalah faktor karakteristik ibu, faktor bayi, lingkungan, dukungan keluarga, pendidikan kesehatan, sosial ekonomi dan budaya. Selain itu, berdasarkan beberapa laporan studi tentang permasalahan pemberian ASI Eksklusif menemukan faktor-faktor tidak diberikannya ASI eksklusif pada bayi adalah karena pengetahuan ibu yang kurang, sikap ibu terhadap pemberian asi ekslusif, ibu sibuk bekerja, pendidikan ibu yang rendah, gencarnya periklanan tentang penggunaan susu formula, kurangnya sekresi ASI, persepsi tentang bayi tanpa diberi makanan tambahan akan menjadi lapar dan pengetahuan ibu tentang ASI kurang (Kearney, 1991; Diharjo, 1998).

Hasil kajian jurnal yang ditemukan oleh Melissa Bartick K, dkk, (2009) 
Dinamika Kesehatan Jurnal Kebidanan dan Keperawatan Vol 10 No. 22019 ( ISSN: 2086-3454 EISSN: 2549-4058)

url: http://ojs.dinamikakesehatan.unism.ac.id DOI: https://doi.org/10.33859/dksm.v10i2

Hubungan Pengetahuan Sikap Ibu Dalam Praktik Pemberian Asi Ekslusif Di Wilayah Kerja Puskesmas Pekapuran Raya Kecamatan Banjarmasin Timur Kota Banjarmasin Tahun 2018

mengatakan bahwa promosi susu formula

berpengaruh terhadap durasi menyusui, pada fasilitas pelayanan kesehatan di US. Penelitian lain yakni, Haydee A.Dabritz, dkk, (2010) di California utara menemukan adanya hubungan antara informasi susu formula melalui telepon, dengan menyusui.

Penelitian lainnya seperti Alex K, dkk. (2007) juga menemukan terjadinya perbedaan respon pemberian ASI eksklusif pada kelompok ibu yang diberi konseling dengan yang tidak diberi konseling. Penelitian lainnya seperti Rafael Perez-Escamilla, (2007); Sandra David, (2008); dan Gloria E, dkk (2009); juga menemukan terjadinya peningkatan pemberian ASI eksklusif pada ibu yang mendapatkan konseling ASI.

Berdasarkan uraian di atas, maka rumusan masalah dalam penelitian ini yaitu mengenai "Bagaimana hubungan pengetahuan ibu terhadap Praktik pemberian ASI eksklusif dan Bagaimana hubungan sikap ibu terhadap pemberian ASI eksklusif.".

\section{Metode}

Penelitian ini merupakan penelitian survey analitik dengan desain penelitian Cross Sectional (studi potong lintang) yang merupakan salah satu jenis rancangan penelitian yang sifatnya analitik dan termasuk dalam jenis rancangan penelitian observasional. Desain ini dimaksudkan untuk mempelajari dinamika dan variasi variabel yang termuat dalam judul penelitian pengetahuan sikap dan pemberian ASI ekslusif di wilayah kerja Puskesmas Pekapuran Raya Kecamatan Banjarmasin Timur.

Besar sampel sampel penelitian adalah sebanyak 91 responden. Hasil pengumpulan data dianalisis dengan menggunakan statistik univariat, bivariate mengunakan uji Analisis hubungan pengetahuan dan sikap terhadap praktek pemberian ASI eksklusif. Analisis hubungan antara variabel independen dan variabel dependen menggunakan uji chisquare dengan batas kemaknaan alpha $=0,05$ atau confidence interval $(\mathrm{CI}=95 \%)$. Untuk bivariat menggunakan uji Chi-square. Hubungan antara variabel bebas dengan skala ordinal terhadap variabel terkait dengan skala 
Dinamika Kesehatan Jurnal Kebidanan dan Keperawatan Vol 10 No. 2 2019 ( ISSN: 2086-3454 EISSN: 2549-4058)

url: http://ojs.dinamikakesehatan.unism.ac.id DOI: https://doi.org/10.33859/dksm.v10i2

Hubungan Pengetahuan Sikap Ibu Dalam Praktik Pemberian Asi Ekslusif Di Wilayah Kerja Puskesmas Pekapuran Raya Kecamatan Banjarmasin Timur Kota Banjarmasin Tahun 2018

ordinal dianalisis dengan uji Chi- Square

untuk mendapatkan hubungan bermakna.

Untuk menentukan apakah terjadi hubungan

yang bermakna antara variabel bebas dan

variabel terkait, maka menggunakan $p$ value

yang dibandingkan dengan tingkat kesalahan

yang digunakan yaitu $5 \%$ atau $0,05 \%$.

Apabila $p$ value $<0,05$, maka Ho diterima,

yang berarti tidak ada hubungan yang

signifikan antara variabel bebas dan variabel

terkait.

\section{Pembahasan}

Hubungan Pengetahuan Sikap Ibu Dalam Praktik Pemberian Asi Ekslusif Di Wilayah Kerja Puskesmas Pekapuran Raya Kecamatan Banjarmasin Timur Kota Banjarmasin.

Tabel 1. Distribusi Frekuensi Responden Berdasarkan Umur

\begin{tabular}{cccc}
\hline No & Umur & $\begin{array}{c}\text { Jumlah } \\
\text { Responden }\end{array}$ & $\begin{array}{c}\text { Presentase } \\
(\mathbf{\%})\end{array}$ \\
\hline 1 & $20-30$ & 56 & 61,54 \\
\hline 2 & $31-40$ & 27 & 29,67 \\
\hline 3 & $>40$ & 8 & 8,79 \\
\hline & Jumlah & $\mathbf{9 1}$ & $\mathbf{1 0 0}$ \\
\hline
\end{tabular}

Tabel 2. Distribusi Frekuensi Responden Berdasarkan Pendidikan Terakhir

\begin{tabular}{cccc}
\hline No & $\begin{array}{c}\text { Pendidikan } \\
\text { Terakhir }\end{array}$ & Jumlah & $\begin{array}{c}\text { Persentase } \\
\mathbf{\%}\end{array}$ \\
\hline 1 & SD & 26 & 28,6 \\
\hline 2 & SMP & 29 & 31.9 \\
\hline 3 & SMA & 33 & 35,2 \\
\hline 4 & D1 & 2 & 2.2 \\
\hline 5 & D3 & 1 & 1.1 \\
\hline & Jumlah & $\mathbf{9 1}$ & $\mathbf{1 0 0}$ \\
\hline
\end{tabular}

Tabel 3. Distribusi Frekuensi Responden Berdasarkan Pekerjaan

\begin{tabular}{cccc}
\hline No & Pekerjaan & Jumlah & $\begin{array}{c}\text { Persentase } \\
\mathbf{\%}\end{array}$ \\
\hline 1 & IRT & 47 & 51.6 \\
\hline 2 & Swasta & 25 & 27.5 \\
\hline 3 & pedagang & 14 & 15.4 \\
\hline 4 & Tani & 5 & 5.5 \\
\hline & Jumlah & $\mathbf{9 1}$ & $\mathbf{1 0 0}$ \\
\hline
\end{tabular}

\section{Analisis Univariat}

Tabel 4. Distribusi Frekuensi Pengetahuan Ibu terhadap Praktik Pemberian ASI Ekslusif di Wilayah Kerja Puskesmas Pekapuran Banjarmasin

\begin{tabular}{llcc}
\hline No & $\begin{array}{c}\text { Pengetahuan } \\
\text { Ibu }\end{array}$ & Jumlah & $\begin{array}{c}\text { Persentase } \\
\mathbf{\%}\end{array}$ \\
\hline 1 & Baik & 51 & 56 \\
\hline 2 & Cukup & 40 & 44 \\
\hline 3 & Kurang & 0 & 0 \\
\hline & Jumlah & $\mathbf{9 1}$ & $\mathbf{1 0 0}$
\end{tabular}

Berdasarkan data yang disajikan pada tabel 4 menunjukkan bahwa sebagian besar responden di Puskesmas Pekapuran Banjarmasin, memiliki tingkat pengetahuan yang baik terhadap Praktik pemberian ASI Ekslusif yaitu sebanyak 51 responden (56\%), dan memiliki pengetahuan cukup sebanyak 40 responden (44\%).

Tabel 5. Distribusi Frekuensi Sikap Ibu terhadap Praktik Pemberian ASI Ekslusif di Wilayah Kerja Puskesmas Pekapuran Banjarmasin

\begin{tabular}{cccc}
\hline No & Sikap Ibu & Jumlah & $\begin{array}{c}\text { Persentase } \\
\mathbf{\%}\end{array}$ \\
\hline 1 & Positif & 62 & 68.1 \\
\hline 2 & Negatif & 29 & 31.9 \\
\hline & Jumlah & $\mathbf{9 1}$ & $\mathbf{1 0 0}$ \\
\hline
\end{tabular}


Dinamika Kesehatan Jurnal Kebidanan dan Keperawatan Vol 10 No. 2 2019 ( ISSN: 2086-3454 EISSN: 2549-4058)

url: http://ojs.dinamikakesehatan.unism.ac.id DOI: https://doi.org/10.33859/dksm.v10i2

Hubungan Pengetahuan Sikap Ibu Dalam Praktik Pemberian Asi Ekslusif Di Wilayah Kerja Puskesmas Pekapuran Raya Kecamatan Banjarmasin Timur Kota Banjarmasin Tahun 2018

Berdasarkan tabel 5 diatas diketahui

Berdasarkan Tabel 7 didapatkan data

sebagian besar responden yang menunjukkan sikap baik terhadap Pemberian ASI Ekslusif yaitu sebanyak 62 responden $(68.1 \%)$ bersikap positif dan sebanyak 29 responden $(31.9 \%)$ yang bersikap negatif.

Tabel 6. Distribusi Frekuensi Praktik Pemberian ASI Ekslusif di Wilayah Kerja Puskesmas Pekapuran Banjarmasin

\begin{tabular}{cccc}
\hline No & $\begin{array}{c}\text { Pemberian } \\
\text { ASI } \\
\text { Ekslusif }\end{array}$ & Jumlah & $\begin{array}{c}\text { Persentase } \\
\mathbf{\%}\end{array}$ \\
\hline 1 & ASI & 57 & 62.6 \\
\hline 2 & Tidak ASI & 34 & 37.4 \\
\hline & Jumlah & $\mathbf{9 1}$ & $\mathbf{1 0 0}$ \\
\hline
\end{tabular}

Berdasarkan tabel 6 di atas menunjukkan bahwa dari 91 ibu yang menjadi responden, ibu yang Aktif memberikan ASI Ekslusif sebanyak 57 orang (62.6\%), dan ibu yang Tidak aktif memberikan ASI sebanyak 34 orang $(37.4 \%)$.

\section{Analisis Bivariat}

Tabel 7. Tabulasi Silang Hubungan Pengetahuan ibu dengan Praktik Pemberian ASI Ekslusif di wilayah Kerja Puskesmas Pekapuran Banjarmasin

\begin{tabular}{|c|c|c|c|c|c|c|c|c|}
\hline \multirow{4}{*}{ No } & \multirow{4}{*}{$\begin{array}{c}\text { Pengeta } \\
\text { huan } \\
\text { Ibu }\end{array}$} & \multicolumn{4}{|c|}{ Praktik Pemberian ASI } & \multirow{3}{*}{\multicolumn{2}{|c|}{ Jumlah }} & \multirow{3}{*}{$\underset{\text { Value }}{\mathbf{p}}$} \\
\hline & & & Eks & & & & & \\
\hline & & \multicolumn{2}{|c|}{ ASI } & \multicolumn{2}{|c|}{$\begin{array}{c}\text { Tidak } \\
\text { ASI }\end{array}$} & & & \\
\hline & & $\mathbf{n}$ & $\%$ & $\mathbf{n}$ & $\%$ & $\mathbf{n}$ & $\%$ & \multirow{4}{*}{0,000} \\
\hline 1 & Baik & 41 & 45 & 10 & 11 & 51 & 56 & \\
\hline 2 & Cukup & 16 & 17.6 & 24 & 26.4 & 40 & 44 & \\
\hline 3 & Kurang & 0 & 0 & 0 & 0 & 0 & 0 & \\
\hline \multicolumn{2}{|c|}{ Jumlah } & 57 & 62.6 & 34 & 37.4 & 91 & $\begin{array}{c}10 \\
0\end{array}$ & \\
\hline
\end{tabular}

bahwa pengetahuan ibu dengan kategori baik proporsinya lebih besar yaitu 51(56\%) orang dengan responden yang aktif dalam praktik meberikan ASI Ekslusif sebanyak 41 orang (45\%) dan yang tidak aktif dalam Praktik meberikan ASI Ekslusif sebanyak 10 orang (11\%). Sedangkan pada kategori cukup ada 40 orang (44\%) dengan jumlah responden yang ASI ekslusif sebanyak 16 orang (17.6\%) dan yang tidak aktif dalam Praktik meberikan ASI Ekslusif sebanyak 24 orang (26.4\%).

Dari hasil uji statistik dengan Fisher's Exact Test didapatkan nilai $\mathrm{p}=0,000$. Nilai $\mathrm{p}$ $=0,000<\alpha=0,05$ maka Ho ditolak dan Ha diterima, artinya ada hubungan yang signifikan antara pengetahuan ibu dengan Praktik Pemberian ASI Ekslusif.

Tabel 8. Tabulasi Silang Hubungan Sikap ibu Praktik Pemberian ASI Ekslusif di wilayah Kerja Puskesmas Pekapuran Banjarmasin.

\begin{tabular}{|c|c|c|c|c|c|c|c|c|}
\hline \multirow[t]{3}{*}{ No } & \multirow[t]{3}{*}{$\begin{array}{c}\text { Sikap } \\
\text { Ibu }\end{array}$} & \multicolumn{4}{|c|}{$\begin{array}{c}\text { Praktik Pemberian ASI } \\
\text { Ekslusif }\end{array}$} & \multirow{2}{*}{\multicolumn{2}{|c|}{ Jumlah }} & \multirow[t]{2}{*}{$\begin{array}{c}\text { p } \\
\text { Value }\end{array}$} \\
\hline & & \multicolumn{2}{|c|}{ ASI } & \multicolumn{2}{|c|}{ Tidak ASI } & & & \\
\hline & & $\mathbf{n}$ & $\%$ & $\mathbf{n}$ & $\%$ & $\mathbf{n}$ & $\%$ & $\overline{0,000}$ \\
\hline 1 & Positif & 50 & 54.9 & 12 & 13.2 & 62 & 68.1 & \\
\hline 2 & Negatif & 7 & 7.7 & $\overline{22}$ & 24.2 & 29 & 31.9 & \\
\hline \multicolumn{2}{|c|}{ Jumlah } & 57 & 62,6 & 34 & 37,4 & 91 & 100 & \\
\hline
\end{tabular}


Dinamika Kesehatan Jurnal Kebidanan dan Keperawatan Vol 10 No. 2 2019 ( ISSN: 2086-3454 EISSN: 2549-4058)

url: http://ojs.dinamikakesehatan.unism.ac.id DOI: https://doi.org/10.33859/dksm.v10i2

Hubungan Pengetahuan Sikap Ibu Dalam Praktik Pemberian Asi Ekslusif Di Wilayah Kerja Puskesmas Pekapuran Raya Kecamatan Banjarmasin Timur Kota Banjarmasin Tahun 2018

Berdasarkan tabel 8 didapatkan data

bahwa sikap ibu dengan kategori positif proporsinya paling besar yaitu 62 orang (68.1\%) dengan jumlah responden yang aktif dalam Praktik Pemberian ASI Ekslusif sebanyak 50 orang $(54.9 \%)$ dan yang tidak aktif dalam Praktik Pemberian ASI Ekslusif sebanyak 12 orang (13.2\%), sedangkan sikap ibu dengan kategori negatif ada 29 orang (31.9\%) dengan jumlah responden yang aktif dalam Praktik Pemberian ASI Ekslusif balita sebanyak 7 orang $(7.7 \%)$ dan yang tidak aktif dalam Praktik Pemberian ASI Ekslusif sebanyak 22 orang $(24.2 \%)$.

Dari hasil uji statistik dengan Fisher's Exact Test didapatkan nilai $\mathrm{p}=0,000$. Nilai $\mathrm{p}$ $=0,000>\alpha=0,05$ maka Ho ditolak dan Ha diterima, artinya ada hubungan yang signifikan antara sikap ibu dengan Praktik Pemberian ASI Ekslusif. Dari hasil penelitian ini menunjukkan bahwa sebagian besar pengetahuan responden tentang Praktik Pemberian ASI Ekslusif sudah baik. Sedangkan pada 40 orang responden yang dikategorikan berpengetahuan cukup, Dari hasil penelitian ini menunjukkan bahwa sikap responden sebagian besar sudah positif terhadap Praktik Pemberian ASI Ekslusif. Menurut Newcomb (Notoatmodjo, 2010: 52), salah seorang ahli psikologis sosial, menyatakan bahwa sikap itu merupakan kesiapan atau kesediaaan untuk bertindak, dan bukan merupakan pelaksanaan motif tertentu. Sikap itu masih merupakan reaksi tertutup, bukan merupakan reaksi terbuka atau tingkah laku yang terbuka. Sikap merupakan kesiapan untuk bereaksi terhadap objek di lingkungan tertentu sebagai suatu penghayatan terhadap objek.

Praktik Pemberian ASI Ekslusif sebanyak 57 orang $(62,6 \%)$, dan yang tidak Praktik Pemberian ASI Ekslusif sebanyak 34 orang $(37,4 \%)$. Keaktifan ibu dalam Praktik Pemberian ASI Ekslusif adalah pertisipasi ibu yang baik mencakup keterlibatan ibu secara aktif dalam pengenalan, pelaksanaan, penilaian dan pembinaan Praktik Pemberian ASI Ekslusif.

Dari hasil uji statistik dengan Fisher's Exact Test didapatkan nilai $\mathrm{p}=0,000$. Nilai $\mathrm{p}$ 
Dinamika Kesehatan Jurnal Kebidanan dan Keperawatan Vol 10 No. 2 2019 ( ISSN: 2086-3454 EISSN: 2549-4058)

url: http://ojs.dinamikakesehatan.unism.ac.id DOI: https://doi.org/10.33859/dksm.v10i2

Hubungan Pengetahuan Sikap Ibu Dalam Praktik Pemberian Asi Ekslusif Di Wilayah Kerja Puskesmas Pekapuran Raya Kecamatan Banjarmasin Timur Kota Banjarmasin Tahun 2018

$=0,000<\alpha=0,05$ maka Ho ditolak dan Ha

diterima, artinya ada hubungan yang signifikan antara pengetahuan ibu dengan Praktik Pemberian ASI Ekslusif. Hasil penelitian ini sejalan dengan penelitian sebelumnya oleh, Marwatik (2007) yang menyatakan bahwa pengetahuan ibu berpengaruh dengan partisipasi ibu terhadap Praktik Pemberian ASI Ekslusif.

Menurut teori pengetahuan adalah merupakan hasil dari "tahu" dan terjadi setelah orang melakukan pengindraan terhadap suatu objek tertentu sehingga dapat menghasilkan berbagai informasi dan pengalaman. Tingkat pengetahuan merupakan domain yang sangat penting dalam bertindak atau terbentuknya perilaku seseorang dengan pengetahuan yang dimiliki dan akan menentukan tindakan lebih lanjut.

Jika tingkat pengetahuan responden baik maka dapat melakukan pemahaman terhadap kegiatan posyandu, kegiatan posyandu yang dihasilkan adalah kunjungan posyandu yang aktif. Menurut Bloom bahwa pengetahuan dapat dikatakan sebagai pengalaman yang berpengaruh pada kecerdasan serta akan meningkatkan minat dan perhatian sehingga semakin tinggi tingkat pengetahuan individu akan sangat membantu dalam menginterprestasikan pengetahuan itu dalam kehidupan sehari-hari.

Dari hasil uji statistik dengan Fisher's Exact Test didapatkan nilai $\mathrm{p}=0,000$. Nilai $\mathrm{p}$ $=0,000>\alpha=0,05$ maka Ho ditolak dan Ha diterima, artinya ada hubungan yang signifikan antara sikap ibu dengan Praktik Pemberian ASI Ekslusif.

Hasil penelitian ini menunjukkan bahwa sikap ibu berpengaruh terhadap Praktik Pemberian ASI Ekslusif. Semakin positif sikap responden maka semakin aktif Praktik Pemberian ASI Ekslusif.

Hasil penelitian ini sejalan dengan penelitian sebelumnya oleh, Moelyani (2009) yang menyatakan bahwa sikap ibu balita tentang kegiatan Praktik Pemberian ASI Ekslusif sangat berpengaruh dengan partisipasi ibu dalam memberikan ASI Ekslusif.

Hal ini sesuai dengan pendapat Newcomb (Notoatmodjo, 2010: 52), salah 
Dinamika Kesehatan Jurnal Kebidanan dan Keperawatan Vol 10 No. 22019 ( ISSN: 2086-3454 EISSN: 2549-4058)

url: http://ojs.dinamikakesehatan.unism.ac.id DOI: https://doi.org/10.33859/dksm.v10i2

Hubungan Pengetahuan Sikap Ibu Dalam Praktik Pemberian Asi Ekslusif Di Wilayah Kerja Puskesmas Pekapuran Raya Kecamatan Banjarmasin Timur Kota Banjarmasin Tahun 2018

seorang ahli psikologis sosial, menyatakan bahwa sikap itu merupakan kesiapan atau kesediaaan untuk bertindak, dan bukan merupakan pelaksanaan motif tertentu. Sikap itu masih merupakan reaksi tertutup, bukan merupakan reaksi terbuka atau tingkah laku yang terbuka. Sikap merupakan kesiapan untuk bereaksi terhadap objek di lingkungan tertentu sebagai suatu penghayatan terhadap objek .

Menurut Allport (1954) dalam Notoatmodjo (2010 : 53), menjelaskan bahwa sikap itu mempunyai 3 komponen pokok, yaitu

a. Kepercayaan (keyakinan), ide, dan konsep terhadap suatu objek.

b. Kehidupan emosional atau evaluasi terhadap suatu objek.

c. Kecenderungan untuk bertindak (tend to behave).

Ketiga komponen ini secara bersamasama membentuk sikap yang utuh (total attitude). Dalam penentuan sikap yang utuh ini, pengetahuan, pikiran, keyakinan, dan emosi memegang peranan penting.

\section{Kesimpulan}

Berdasarkan hasil penelitian yang dilakukan Dari hasil penelitian tentang "Hubungan Pengetahuan, Sikap ibu dengan Praktik Pemberian ASI Ekslusif di Wilayah Kerja Puskesmas Pekapuran Banjarmasin" Sebagian besar responden di wilayah kerja Puskesmas Pekapuran Banjarmasin, memiliki tingkat pengetahuan yang baik terhadap Pemberian ASI Ekslusif sebanyak 51 responden atau $(56,0 \%)$, dan berpengetahuan cukup sebanyak 40 responden atau $(44,0 \%)$. Sebagian besar responden di wilayah kerja Puskesmas Pekapuran Banjarmasin, yang menunjukan sikap positif terhadap Pemberian ASI Ekslusif sebanyak 62 responden atau $(68,1 \%)$, dan sikap negatif sebanyak 29 responden atau (31,9\%). Sebagian besar responden di wilayah kerja Puskesmas Pekapuran Banjarmasin, ibu yang aktif dalam Pemberian ASI Ekslusif sebanyak 57 orang $(62,6 \%)$, dan yang tidak aktif dalam Pemberian ASI Ekslusif sebanyak 34 orang (37,4\%). Ada hubungan yang signifikan antara variabel bebas yaitu pengetahuan ibu dengan variabel terikat yaitu Pemberian ASI Ekslusif (p value 
$=0,000)$ di wilayah kerja Puskesmas

Pekapuran Banjarmasin. Ada hubungan yang signifikan antara variabel bebas yaitu sikap ibu dengan variabel terikat yaitu Pemberian ASI Ekslusif $(\mathrm{p}$ value $=0,000)$ di wilayah kerja Puskesmas Pekapuran Banjarmasin.

\section{Daftar Pustaka}

American Heart Association. (2014). How potassium can help control high blood pressure. Dipetik Oktober 25, 2017, dari American Heart Association:http://www.heart.org/ HEARTORG/Conditions/HighBlo od Pressure/ Make Changes That Matter/How-Potassium-CanHelp-Control-High-BloodPressure_UCM_303243_Article.js p \# main Content

Black JM, Hawks J. 2013. Medical surgical nursing : clinical management for positive outcomes. Edisi ke-8. USA: Elsevier Saunders.

Black, J. M., \& Hawks, J. H. (2014). Keperawatan Medikal Bedah : Manajemen Klinis untuk Hasil yang Diharapkan Edisi 8 Buku 2. Indonesia: PT Salemba Medika.

Dalimartha S. Tanaman Obat di Lingkungan Sekitar. Jakarta: Puspa Swara; 2005. p.39

Dalimartha, Setiawan, dkk. 2008. Care Your Self, Hipertensi. Depok : Penebar Plus.

Haveles E. Applied pharmacology for the dental hygienist. 6th edition. Misouri : Mosby Elsevier. 2011. Andari I, Wahyono D.
James PA, Oparil S, Carter BL, Cushman WC, Dennison-himmelfarb $\mathrm{C}$, et al. 2013. 2014 evidence-based guideline for the management of high blood pressure in adults report from the panel members appointed to the eighth joint national committee (jnc 8). JAMA. 311(17):1809.

Kurniawati N, Tim Redaksi Qanita. Sehat \& cantik alami berkat khasiat bumbu dapur.Jakarta: qanita; 2010.p. 90-1

Masriadi, H. 2016. Epidemiologi Penyakit Tidak Menular. Jakarta : CV. Trans Info Media, Hal. 359-370.

Notoatmodjo S. 2010. Metodologi penelitian. Jakarta: Rineka Cipta.

Nurarif, A. H., \& Kusuma, H. (2015). Aplikasi Asuhan Keperawatan Berdasarkan Diagnosa Medis \& NANDA NIC-NOC. Jogjakarta: Mediaction.

Potter, P.A., \& Perry, A. G. (2005). Fundamental Keperawatan Volume 1 Edisi 4. Jakarta: EGC.

Price SA, Wilson LM. 2002. Pathophysiology: clinical concepts of disease processes. Edisi ke-6. New York: Elsevier Science Health Science.

Sherwood, L. (2013). Fisiologi Manusia Dari Sel Ke Sistem Edisi 6. Jakarta: EGC.

Sugiyono. (2010). Metode Penelitian Kuantitatif Kualitatif dan $R \& D$. Bandung: Alfabeta.

Sumono A \& Wulan A. The use of bay leaf (Eugenia polyantha Wight) in dentistry. Dental Jurnal . 2008; 41(3). 
Sumono A, Wulan A. Kemampuan air rebus daun salam (Eugenia polyantha w) dalam menurunkan jumlah koloni bakteri streptococcus sp. Majalah Farmasi Indonesia, 20 (3), 112-7, 2009.

Syaifuddin, M. (2013). Penggunaan

Tanaman Herbal Pada Lansia

Penderita Hipertensi Di

Kecamatan Gatak Kabupaten

Sukoharjo. Surakarta: Fakultas

Ilmu Kesehatan Universitas

Muhammadiyah.

World Health Organization. 2003. 2003 world health organization (who)/international society of hypertension (ish) statement on management of hypertension. $\mathbf{J}$ Hypertens. 21(11):1983-1992.

World Health Organization. 2003. Adherence to long-term therapies.

WHO. 2013. 2015. World Health Statistic 2015. Available from : http://apps.who.int/iris/bitstream/10 665/170250/1/9789240694439_eng . pdf [Diakses 8 April 2017]

Winarto WP, Tim Karyasari. Mememanfaatkan bumbu dapur untuk mengatasi aneka penyakit. Jakarta: Agromedia Pustaka; 2004.p.50 